Al-Bayyinah: Journal of Islamic Law-ISSN: 1979-7486 (p); 2580-5088 (e) Volume VI Number 1, pp. 59-74

\title{
HAK KEWARISAN PADA KARYA CIPTA INTELEKTUAL
}

\section{Hj. Hamsidar}

(Dosen Tetap STAIN Watampone, Sulawesi Selatan, Indonesia, email: hamsidar.iainbone@gmail.com

\section{Abstract}

The principal problem in this writing is how is inherit status of intellectual copyright in Islamic law and positive law. In Islamic and positive law perspective, intellectual copyright is considered as the creator property and categorized as the property which can be inheritance, even partly totally. The ownership right to the intellectual copyright with inheriting cause is considered as a way to get property legally.

\section{Kata Kunci: Kewarisan, Hak Cipta dan Intelektual}

\section{PENDAHULUAN}

\section{A. Latar Belakang}

Harta merupakan salah satu unsur yang amat penting dalam kehidupan manusia. Hal itu disebabkan ia merupakan alat untuk memenuhi keperluan dan kebutuhan hidup. Bahkan, dalam maqashid al-syari'ah harta dipandang sebagai salah satu unsur yang dilindungi dan dipelihara dalam rangka mewujudkan kemaslahatan hidup. ${ }^{1}$ Oleh karena harta dipandang sebagai sesuatu yang asasi dalam kehidupan manusia, maka Islam telah menegaskan bahwa harta diperoleh melalui cara yang baik dan digunakan untuk kebaikan.

Kaitannya dengan hal tersebut, dalam memperoleh harta benda dapat dilakukan dengan cara yang beraneka ragam, antara

1 Lihat, Cik Hasan Bisri (Peny), Hukum Islam dalam tatanan Masyarakat Indonesi (Cet. I; Jakarta: Logos, 1999), h.159. 
lain melalui warisan. ${ }^{2}$ Kepemilikan harta akibat kewarisan dipandang sebagai jalan yang dibenarkan dalam Islam, bahkan hak kewarisan seseorang berlangsung secara otomatis dan wajib diberikan sepanjang tidak terhalang oleh syar'i. Dengan demikian, tidak berlebihan jika dikatakan bahwa perolehan harta benda melalui jalan kewarisan dipandang sebagai hak mutlak yang diakui keabsahannya secara mutlak pula oleh syari'at Islam.

Kendatipun kepemilikan harta benda melalui jalan kewarisan mempunyai landasan hukum yang kuat, akan tetapi dalam kenyataan masalah harta warisan menjadi permasalahan umat Islam. Oleh karena itu, masalah kewarisan mendapat perhatian yang sangat serius dalam Islam. Hal itu disebabkan pembagian harta warisan seringkali menjadi sumber permasalahan dalam kehidupan keluarga, dan berimplikasi pada kehidupan kemasyarakatan secara umum. Sehubungan dengan hal tersebut, menurut Satria Effendy bahwa dari sekian banyak aspek kehidupan yang diatur dalam Alquran, masalah kewarisan merupakan masalah yang paling rinci diatur dalam Alquran. ${ }^{3}$

Dalam konteks tersebut, salah satu masalah kewarisan yang banyak diperdebatkan adalah hak cipta. Disatu sisi, hak cipta dipandang sebagai harta yang dapat diwariskan kepada ahli waris sebagaimana halnya warisan harta dapat diwariskan kepada ahli waris karena ia merupakan hak khusus bagi penemunya dan kepemilikannya tidak dapat dialihkan kepada orang lain selain penemunya.

\section{B. Rumusan Masalah}

Studi tentang hak cipta yang berkaitan dengan kewarisan dipandang sangat penting. Oleh karena itu, status kewarisan hak cipta merupakan masalah keumatan yang sangat asasi, tidak hanya menyangkut hak kewarisan, tetapi juga menyangkut masalah umat dan kemasyarakatan. Oleh karena itu, permasalahan pokok yang akan dikaji dalam tulisan ini adalah

${ }^{2}$ Lihat, Huzaimah T Yanggo dan Hafiz Anshary (Ed), Problematika Hukum Islam Kontemporer (Cet. I; Jakarta: IKAPI, 1995), h.110.

${ }^{3}$ Lihat, Satria Efendi M. Zein, Analisis Fiqh, dalam Mimbar Hukum Aktualisasi Hukum Islam, Nomor 30 Thn. VIII, 1997 (Jakarta: Al-Hikmah dan Ditbinbapera Islam), h.104. 
bagaimana hak kewarisan pada hak cipta intelektual dalam perspektif hukum Islam dan hukum positif?

\section{Kerangka Teori}

Sebelum lebih jauh memasuki pembahasan tentang masalah yang akan dikaji dalam tulisan ini, maka perlu diberikan batasan pengertian terhadap beberapa kata yang dianggap penting dalam judul ini, yaitu sebagai berikut:

1. Status. Kata itu menunjukkan kepada arti keadaan atau kedudukan seseorang atau badan dalam hubungannya dengan masyarakat disekitarnya. ${ }^{4}$

2. Hukum kewarisan. Dalam kamus bahasa Indonesia tidak ditemukan istilah hukum kewarisan, akan tetapi hanya dikemukakan tentang hukum waris yang dimaknai dengan hukum yang mengatur tentang nasib harta peninggalan pewaris.

3. Hak Cipta Intelektual. Hak cipta intelektual dalam kajian hukum diartikan sebagai hak khusus yang diberikan oleh pemerintah kepada seseorang yang telah menciptakan sesuatu berdasarkan pemikirannya atau keahliannya dalam bidang ilmu pengetahuan, sastra dan seni. ${ }^{6}$

4. Hukum Positif. Dalam kamus Bahasa Indonesia, dikemukakan bahwa penggabungan dua kata itu diartikan dengan hukum atau peraturan perundangundangan yang berlaku secara positif dalam suatu Negara. $^{7}$

5. Hukum Islam. Dalam kamus Bahasa Indonesia disebutkan bahwa hukum Islam adalah peraturanperaturan dan ketentuan-ketentuan yang berkenaan dengan kehidupan manusia yang berdasarkan dengan kitab Alquran. ${ }^{8}$ Hasbi Ash-shiddiqy memberikan definisi bahwa hukum Islam adalah koleksi daya upaya para

4 Lihat Tim Penyusun, Kamus Besar Bahasa Indonesia (Cet. II; Jakarta: Balai Pustaka, 2002), h.1090.

${ }^{5}$ Lihat Ibid., h.441.

${ }^{6}$ Lihat, Richard Burton Simatupang, Aspek Hukum dalam Bisnis (Cet. I; Jakarta: Rineka Cipta, 1996), h.87.

${ }^{7}$ Tim Penyusun, op.cit., h.411.

8 Departemen Pendidikan dan Kebudayaan, Kamus Besar Bahasa Indonesia (Cet. III; Jakarta: Balai Pustaka, 1990), h.315. 
fukaha dalam menerapkan syari'at Islam sesuai dengan kebutuhan masyarakat. ${ }^{9}$ Sedangkan dalam kajian ushul fikih, hukum Islam adalah Khitab (baca; Firman) Allah yang berkaitan dengan perbuatan mukallaf. Dalam istilah lain, hukum Islam adalah seperangkat aturan yang diterapkan secara langsung dan tegas oleh Allah atau ditetapkan pokok-pokoknya untuk mengatur tata hubungan antara manusia dengan Tuhannya, manusia dengan sesamanya, manusia dengan lingkungan alamnya. ${ }^{10}$ Dengan demikian, pada prinsipnya hukum Islam adalah seperangkat ketentuan dan peraturan yang berdasarkan dengan ajaran Islam dan bertujuan untuk mengatur hajat hidup manusia baik di dunia maupun di akhirat. Dalam istilah yang sederhana hukum Islam adalah tata peraturan dan ketentuan yang bersumber dari Alquran dan Hadis bertujuan untuk mengatur tentang perbuatan mukallaf agar memperoleh keselamatan, baik di dunia maupun akhirat. Di Indonesia istilah hukum Islam diasosiasikan dengan al-Fiqh al-Islam. Dengan demikian, hukum Islam adalah peraturan yang dirumuskan berdasarkan wahyu Allah dan Sunnah Rasul tentang tingkah laku mukallaf yang diakui dan diyakini berlaku mengikat bagi semua pemeluk Islam. ${ }^{11}$

Beberapa pengertian tersebut, menjadi kerangka teoritis sebagai acuan dalam mengkaji status hukum kewarisan terhadap hak cipta intelektual berorientasi untuk menegaskan kedudukan hukum kewarisan terhadap hak cipta dalam sistem hukum Islam dan hukum positif yang berlaku di Indonesia.

\section{Metode Penelitian}

1. Metode Pengumpulan Data

${ }^{9}$ Hasbi Ash-Shiddiqy, Filsafat Hukum Islam, (Cet.III; Jakarta: Bulan Bintang, 1985), h.44.

10 Lihat, Ibrahim Hosen, Fungsi dan Karakteristik Hukum Islam dalam Kehidupan Umat Islam, dalam Amrullah Ahmad SF, Dimensi Hukum Islam dalam Sistem Hukum Nasional (Cet.I; Jakarta: Gema Insani Press, 1996), h.86-87.

11 Ahmad Rofiq, Hukum Islam Indonesia (Cet.II; Jakarta: Raja Grafindo Persada, 1997), h.8. 
Oleh karena penelitian ini bersifat teoretis, maka pengumpulan data yang dibutuhkan dilakukan melalui library research (baca: Penelitian kepustakaan) yaitu mengulas, menyadur, dan mengutip bahan-bahan dari kepustakaan yang ada kaitannya dengan masalah yang dibahas, baik dalam bentuk buku, makalah, dan artikelartikel yang dianggap representatif.

2. Metode Analisis Data

Dalam pengelolaan data, penulis menggunakan analisis kualitatif, berupa usulan, gagasan, dan pendapat para pakar atau ulama khususnya hukum Islam. Datadata yang diklasifikasikan selanjutnya dianalisis dengan menggunakan teknik dan metode:

a. Deduktif (deduksi), yaitu sejumlah data sifatnya umum dan dikembangkan secara silogisme untuk selanjutnya ditarik suatu simpulan yang runtut.

b. Induktif, yaitu dari data yang sifatnya khususnya ditarik simpulan yang sifatnya umum.

\section{PEMBAHASAN}

\section{A. Hak Kewarisan terhadap Hak Cipta Intelektual Menurut Perspektif Hukum Islam}

Manusia dikaruniai oleh Allah naluri, nilai dan kemampuan untuk mengapresiasi pikiran, gejolak jiwa dan kehendak hatinya. Pada suatu waktu manusia terdorong untuk mencurahkan isi pikiran dan hati nuraninya dalam bentuk tertentu, misalnya berupa karangan, seni sastra, musik, lukis, pahat dan lain-lain. Ekspresi seni yang demikian disebut dengan istilah ciptaan atau karya. Demikian pula halnya dengan ekspresi pikiran atau gagasan yang dituangkan dalam bentuk karya ilmiah, disebut dengan istilah hasil cipta ilmiah atau intelektual. ${ }^{12}$

Dengan demikian, suatu karya cipta lahir dari proses kerja seseorang dengan menggunakan potensinya yang disebut dengan istilah ciptaan. Sedangkan orang yang melahirkan

${ }^{12}$ Lihat, Zuhad, Pandangan Hukum Islam Terhadap Pembajakan dan Akibat Hukumnya, dalam Huzaimah T. Yanggo dan Hafiz Anshary (ed.), Problematika Hukum Islam Kontemporer, Cet. I; Jakarta: LSIK, 1995), h.102. 
ciptaan disebut pencipta. Dalam hal ini, pencipta adalah seorang atau beberapa orang yang secara bersama-sama berdasar inspirasinya melahirkan suatu ciptaan yang bersumber dari kemampuan pikiran, imajinasi, kecekatan, keterampilan atau keahlian yang dituangkan dalam bentuk yang khusus dan bersifat pribadi. Dalam hal ini, ciptaan yang dimaksud adalah yang timbul dari lapangan ilmu, seni dan sastra. ${ }^{13}$

Dipahami dari pengertian diatas bahwa ciptaan pada dasarnya meliputi unsur sebagai berikut:

1. Ciptaan adalah buah pikiran yang bersifat non materil, yaitu bukan bendanya seperti buku. Dikatakan demikian sebab benda pada hakikatnya merupakan tempat dan sarana mendapatkan manfaat dan sebagai standar penilaian ciptaan.

2. Ciptaan berarti sesuatu yang baru, bukan pengulangan dan peniruan bentuk lain yang telah mendahuluinya. Oleh karena itu, suatu terjemahan dapat dikategorikan sebagai karya cipta, karena dalam menerjemahkan seseorang dituntut memiliki kemampuan ilmiah, pemahaman yang mendalam tentang bahasa yang diterjemahkan dan usulnya. ${ }^{14}$

Kaitannya dengan hal tersebut, sifat dasar ciptaan atau karya intelektual pada dasarnya manunggal dengan diri pencipta. Itu berarti bahwa pencipta mempunyai hak atas ciptaannya, baik berupa hak materil yang didapat imbalannya di dunia, maupun hak secara materil yang didapat pahalanya di akhirat. Hak seseorang atas suatu hasil karya intelektual yang bersifat duniawi meliputi hak untuk mendapat manfaat materil dan hak untuk mendapatkan pengakuan atas karyanya. Sedangkan hak yang bersifat ukhrawi adalah pahala yang diberikan oleh Allah atas karya ciptaannya yang memberikan manfaat kepada orang lain dan berlangsung terus walaupun pencipta sudah meninggal dunia.

Dengan demikian, hak pencipta atas karya cipta intelektualnya dapat dialihkan kepada seseorang atau lembaga,

13 Lihat, H.M.N. Purwosutjipto, Pengertian Pokok Hukum Dagang Indonesia, (Jakarta: Jambatan, 1988), h.114.

${ }^{14}$ Lihat, Huzaimah T. Yanggo dan Hafiz Anshary (ed.), Problematika Hukum Islam Kontemporer, (Cet. I; Jakarta: LSIK, 1995), h.103. 
badan atau perusahaan untuk digunakan dan dimanfaatkan. ${ }^{15}$ Apabila suatu hasil karya cipta seseorang atau beberapa orang diamalkan oleh pencipta atau orang lain untuk kemaslahatan umat, maka hal itu disebut sebagai amal shaleh, dan orang yang beramal shaleh berhak mendapat pahala atas amal-amal yang dilakukan. Namun demikian, hak seseorang untuk mendapatkan pahala atas karya ciptaannya tidak dapat dialihkan kepada orang lain atau badan. Oleh karena itu, hak cipta atas suatu karya intelektual dikatakan sebagai hak yang manunggal atas diri penciptanya dan bersifat pribadi karena tidak dapat dialihkan. ${ }^{16}$

Dalam konteks tersebut, berbicara tentang hak cipta intelektual sangat erat kaitannya dengan harta yang mengandung hak. Sedangkan dalam perspektif fikih, terdapat beberapa teori tentang harta, antara lain:

1. Menurut ulama Hanafiyah bahwa harta adalah segala sesuatu yang mungkin disimpan dan bisa dimanfaatkan secara biasa. Definisi itu mengandung dua unsur, yakni: pertama, dapat disimpan, berarti sesuatu yang tidak dapat disimpan tidak dianggap sebagai harta, seperti halhal yang bersifat maknawi seperti ilmu. Kedua, dapat dimanfaatkan secara biasa. ${ }^{17}$

2. Menurut jumhur ulama bahwa harta adalah segala sesuatu yang mempunyai nilai (qimah) dan orang yang merusaknya wajib menanggung beban (dlaman).

Pernyataan jumhur ulama tentang harta menekankan pada aspek nilai, sesuatu yang bernilai bagi manusia disebut dengan harta dan padanya melekat suatu hak. Implikasinya adalah apabila harta diganggu atau dirusak oleh seseorang, maka orang yang merusaknya wajib menanggung beban. Hal itu berarti bahwa setiap yang mempunyai nilai berarti mempunyai manfaat, sebab tidak ada nilainya sesuatu yang tidak memberi manfaat. Oleh karena itu, sesuatu yang tidak memiliki nilai dan manfaat tidak dipandang sebagai harta dan akan ditinggalkan oleh manusia. Dengan demikian, dapat dipahami bahwa nilai merupakan argumentasi epistemologis sehingga sesuatu dapat

${ }^{15}$ Lihat, Zuhad, op.cit., h.104.

${ }^{16}$ Lihat, Ibid., h.103.

17 Wahbah al-Zuhaily, al-Fiqh al-Islamiy wa Adillatuh, IV, (Beirut: Dar al-Fikr, 1982), h.11. 
dipandang sebagai harta, dan nilai pada dasarnya adalah manfaat itu sendiri. Konkritnya adalah manfaat merupakan asal dalam memberi nilai dan memandang sesuatu. Hal itu sesuai dengan pandangan al-'Iz ibn Abd al-Salam yang mengatakan bahwa:

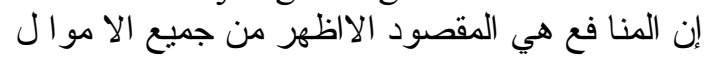

Artinya: Pada dasarnya manfaat adalah maksud yang nyata dari semua harta. ${ }^{18}$

Pada yang senada juga dikemukakan oleh Ibn Khaldun bahwa pekerjaan ( $a^{\prime} m a l$ ) termasuk harta atau sesuatu yang dianggap harta. Oleh karena itu, membebankan pekerjaan dan memaksa orang lain bekerja tanpa upah adalah suatu kedzaliman yang amat besar dan sangat merusak tata pembangunan dan kemakmuran. Dikatakan demikian karena segala pekerjaan (a'mal) ditinjau dari segi nilainya, sehingga orang yang bekerja dalam membangun kehidupan dan usaha mereka dinilai dari manfaat yang dapat mereka sumbangkan. Jika mereka dibebani pekerjaan diluar beban mereka dan dipaksa bekerja tanpa upah, yang memerintah telah bertindak sebagai perampas nilai amal mereka (rakyat). ${ }^{19}$

Mengacu pada pandangan ulama Hanafiyah, maka sesuatu dipandang sebagai harta apabila berwujud benda materi (a'yan madiyah) atas sesuatu yang mempunyai materi dan benda yang kasat mata. Oleh karena itu, manfaat dan hak tidak termasuk harta, akan tetapi termasuk milik. Berbeda dengan pandangan jumhur ulama yang menganggap bahwa manfaat dan hak termasuk dalam pengertian sebagai harta. Dikatakan demikian karena maksud dari sesuatu adalah manfaatnya, bukan semata-mata bendanya. ${ }^{20}$

Teori-teori tentang harta diatas memberikan qiyasan bahwa hasil karya ciptaan ilmiah adalah pekerjaan akal dan merupakan karya, maka ia dipandang sebagai harta. Dalam hal ini, sesuatu yang asalnya belum merupakan harta, apabila

${ }^{18}$ Lihat, al-'Iz bin Abd. Al-Salam, Qawa'id al-Ahkam, II, (Qahirah: Maktabah al-Kulliyat al-Ashariyah, 1968), h.17.

${ }^{19}$ Lihat, Ibn Khaldun, Muqaddimah, (Qahidah: Mathba'ah Mustafah Muammad, t.th.), h.28.

${ }^{20}$ Wahbah al-Zuhaely, op.cit., h.42. 
dikemudian hari tampak manfaatnya, maka dapat dikategorikan sebagai harta selama memberikan manfaat bagi manusia secara umum. Dengan demikian, jika manfaat dikategorikan sebagai harta sebagaimana berlaku juga hak milik seperti terhadap benda, selama pemanfaatannya itu mubah secara syar'i. Dalam jual beli dan tukar menukar dasarnya adalah hak milik. Oleh karena itu, secara adat telah berlaku terhadap karya cipta intelektual. $^{21}$

Pada konteks itu, dapat dikatakan bahwa karya cipta intelektual adalah harta yang mempunyai kedudukan yang vital bagi pembangunan peradaban manusia. Dikatakan demikian karena karya cipta intelektual merupakan kemaslahatan umum yang hakiki. Oleh karena itu, hak para penciptanya perlu dilindungi dengan Undang-Undang dalam rangka menjaga hak dan kepentingan dan demi menegakkan keadilan di tengah masyarakat. Penalaran itu sesuai dengan jiwa dan tujuan syari'at untuk mengambil maslahat dan menolak mudharat. ${ }^{22}$

Kaitannya dengan hal tersebut, Ibn 'Arafah dalam mendefenisikan harta menekankan pada arti dan sifat kehartaan. Hal itu dapat dilihat pada ungkapannya sebagai berikut:

ظاهر المال يشمل العين و العرض

Artinya: Harta secara lahir mencakup benda ('ain) yang bisa diindera dan benda ('ard) yang tidak bisa diinderakan (manfaat). $^{23}$

Pandangan Ibn 'Arafah tersebut, tampaknya lebih mendekati dan sesuai dengan sifat karya cipta intelektual. Dikatakan demikian karena Ibn 'Arafah menafsirkan kata "al"aradh" sebagai manfaat atau makna yang secara akal tidak mungkin menunjukkan kepadanya. Oleh karena itu, istilah al'ardh mencakup karya cipta yang sebenarnya merupakan pemikiran manusia yang tidak mungkin dimanfaatkan kecuali

${ }^{21}$ Lihat, Zuhad, op.cit., h.105.

${ }^{22}$ Lihat, al-'Iz bin Abd. Al-Salam, op.cit., h.160.

23 Lihat, Fathi al-Daraini, al-Fiqh al-Islami al-Muqaran Ma'a alMazahib, (Damsyiq: Mathba'ah Thurbin, t.th.), h.248. 
mengaitkannya kepada pencipta dan sumbernya yang mengambil bentuk materi seperti buku dan lainnya. ${ }^{24}$

Dengan demikian, Islam memandang bahwa karya cipta intelektual sebagai harta dan pemiliknya harus dilindungi sebagai perwujudan dari tujuan syari'at untuk memelihara harta. Sebaliknya apabila karya cipta intelektual tidak diakui sebagai harta dan sebagai hak milik bagi penciptanya, maka akan membawa kepada terputusnya kreativitas intelektual untuk mencipta. Itu berarti bertentangan roh syari'at yang menganjurkan setiap manusia untuk beramal dan berkreasi demi kemaslahatan umum. Dengan demikian, memberikan perlindungan hukum kepada hak cipta intelektual dipandang sebagai kewajiban syar'I dalam rangka menjaga karya cipta seseorang sebagai penjagaan terhadap hak atas harta yang bersifat manusiawi.

Kaitannya dengan hal tersebut, hak pencipta terhadap karya intelektualnya adalah hak individu sebagai harta yang melekat pada dirinya. Dalam pandangan hukum Islam, hak pencipta adalah hak yang diakui dan dapat berpindah kepemilikannya. Dikatakan demikian karena hak milik terhadap karya cipta intelektual dikategorikan sebagai benda bergerak. Sedangkan menurut ulama Hanafiyah, Malikiyah dan Ahmad bin Hanbal bahwa hak milik terhadap harta atau benda bergerak dapat berpindah tangan hak kepemilikannya. ${ }^{25}$

Dalam perspektif hukum Islam peralihan atau perpindahan hak kepemilikan terhadap harta benda dapat terjadi karena beberapa faktor, antara lain kewarisan, wasiat dan hibah. $^{26}$ Sedangkan untuk mendapatkan hak kepemilikan melalui pewarisan dapat terjadi oleh tiga sebab yaitu; adanya hubungan nasab, adanya hubungan perkawinan dan hubungan al-wala' (hubungan pembebasan budak). ${ }^{27}$

${ }^{24}$ Ibid., h. 234.

${ }^{25}$ Lihat, Zuhad, op.cit., h.107.

${ }^{26}$ Lihat, pasal 71 Kompilasi Hukum Islam, dalam Abd. Rahman, Kompilasi Hukum Islam di Indonesia, (Cet. I; Jakarta: Akademika, 1992), h.155-156.

${ }^{27}$ Wahbah al-Zuhaily, al-Fiqh al-Islam wa Adillahtuh, Juz VIII (Cet. III; Beirut: Dar al-Fikr, 1989), h.200. Lihat juga Muh. Jawad Mughniyah, alFiqh 'ala Mazahib al-Khamzah, diterjemahkan oleh Afif Muhammad dengan judul, Fikih Lima Mazhab, Jilid II (Cet. I; Jakarta: Basrie Press, 1994), h.279. 
Peralihan hak kepemilikan atas hak cipta intelektual karena sebab kewarisan, maka ahli waris mempunyai hak penuh terhadap hak cipta intelektual yang telah diwarisi. Itu berarti bahwa ahli waris dapat bertindak dan bertransaksi sepenuhnya terhadap hak cipta intelektual sebagaimana kebolehan pewaris sebelum meninggal dunia. Dikatakan demikian karena hak cipta intelektual yang diwarisi telah menjadi hak miliknya dan menjadi bagian dari kekayaannya serta dapat diwariskan.

\section{B. Status Kewarisan Hak Cipta Intelektual dalam Perspektif Hukum Positif}

Perkembangan ekonomi global dewasa ini, telah melahirkan berbagai problematika hukum yang harus segera direspon oleh umat Islam. Salah satu aspek yang menarik dalam perkembangan dunia perekonomian adalah tentang hak cipta intelektual. Problematika hak cipta intelektual tampaknya tidak berdiri sendiri, akan tetapi terkait dengan aspek-aspek lainnya. Dalam artian bahwa hak cipta intelektual, di samping terkait dengan masalah ekonomi juga terkait dengan aspek hukum. Bahkan tidak berlebihan jika dikatakan bahwa problema hukum sangat riskan dan penting untuk dibicarakan dalam masalah hak cipta intelektual. Dikatakan demikian karena aspek hukum pada hak cipta intelektual dipandang sebagai landasan dan kekuatan untuk mendapat hak-hak ekonomis dan hak-hak lainnya.

Dengan demikian, urgensi aspek hukum pada hak cipta intelektual dapat dilihat dari segi budaya, ekonomi dan sosial. Dari segi budaya, aspek hukum mempunyai pretense yang sangat penting dalam memberikan perlindungan hukum terhadap hak cipta intelektual sebagai bagian dari pelestarian dan pengembangan kreativitas budaya bangsa. Sedangkan dari segi ekonomis, aspek hukum pada hak cipta intelektual berpretensi untuk memberikan kepastian hukum terhadap pencipta untuk mempertahankan dan mendapatkan hak-haknya atas karya cipta intelektualnya. Demikian pula dari segi sosial, aspek hukum akan memberikan jaminan terjaga dan terpeliharanya nilai-nilai sosial pada hak cipta intelektual dalam memberikan kemaslahatan pada umat manusia.

Lebih jauh berbicara tentang aspek hukum, maka hak cipta intelektual dapat dikategorikan sebagai benda tak bergerak. 
Hal ini sesuai dengan ketentuan dalam undang-undang Nomor 19 tahun 2002 tentang Hak Cipta pasal 3 ayat 1 dikatakan bahwa hak cipta dikategorikan sebagai benda bergerak. Oleh karena itu, hak cipta intelektual dipandang sebagai kekayaan pencipta secara individu dan berhak sepenuhnya atas ciptaannya. $^{28}$ Dengan demikian, hak cipta intelektual sebagaimana dengan benda bergerak lainnya dapat dialihkan atau dipindahkan kepemilikannya sesuai dengan ketentuan yang berlaku.

Dalam konteks tersebut, status hak cipta intelektual sebagai benda tidak bergerak menunjukkan bahwa hak cipta intelektual merupakan harta warisan yang dapat diwariskan kepada ahli warisnya. Hal itu dipahami dari ketentuan pasal 3 ayat 2 Undang-undang Nomor 19 tahun 2002 bahwa hak cipta intelektual dapat beralih atau dialihkan hak kepemilikannya terhadap hak cipta (intelektual), dapat terjadi karena beberapa sebab, yaitu: pewarisan, hibah, wasiat, perjanjian tertulis dan sebab-sebab lain yang dibenarkan oleh Undang-undang. ${ }^{29}$

Peralihan hak cipta intelektual karena sebab pewarisan terjadi secara otomatis. Dalam artian bahwa apabila pencipta suatu karya intelektual meninggal dunia dan ciptaannya oleh undang-undang diakui sebagai hak cipta, maka hak kepemilikannya beralih atau berpindah secara otomatis kepada ahli warisnya. Hal itu sesuai dengan ketentuan pasal 4 ayat 1 Undang-undang nomor 19 tahun 2002 tentang Hak Cipta bahwa hak cipta yang dimiliki oleh pencipta yang telah meninggal dunia, menjadi milik ahli warisnya atau milik penerima wasiat dan hak cipta tersebut tidak dapat disita kecuali jika hak itu diperoleh secara melawan hukum. ${ }^{30}$ Dengan demikian, hak kepemilikan terhadap hak cipta intelektual karena sebab pewarisan, menyebabkan ahli waris mempunyai hak penuh terhadap karya intelektual yang diwarisinya. Oleh karena itu, tidak boleh dilakukan perubahan terhadap suatu hak cipta

${ }^{28}$ Lihat, Undang-Undang Nomor 19 Tahun 2002 tentang Hak Cipta.

${ }^{29}$ Lihat, Undang-Undang Nomor 19 Tahun 2002 tentang Hak Cipta pasal 3 ayat 2 .

${ }^{30}$ Lihat, Undang-Undang Nomor 19 Tahun 2002 tentang Hak Cipta pasal 4 ayat 1 . 
walaupun telah diserahkan kepada orang lain kecuali dengan persetujuan ahli warisnya.

Kendatipun peralihan hak cipta intelektual kepada ahli warisnya berlangsung secara otomatis setelah pewaris meninggal dunia, dalam penjelasan pasal 3 ayat 2 UndangUndang Nomor 19 Tahun 2002 tentang Hak Cipta dijelaskan bahwa peralihan hak kepemilikan terhadap hak cipta (intelektual) tidak dapat dilakukan secara lisan, akan tetapi harus dilakukan secara tertulis baik dengan maupun tanpa akta notaris. $^{31}$

Namun demikian, menurut penulis bahwa hal itu tidak berarti mementahkan peralihan hak kepemilikan secara otomatis karena sebab pewarisan. Melainkan semata-mata dimaksudkan untuk menghindari saling sengketa dikemudian hari, khususnya antara ahli waris dan penerima wasiat atau hibah. Dalam artian bahwa keharusan peralihan secara tertulis dimaksudkan untuk menghindari adanya justifikasi pihak tertentu sebagai pihak yang mendapat wasiat atau hibah secara lisan dari pewaris, baik dari pihak ahli waris maupun orang lain.

Mengacu pada uraian tersebut, dipahami bahwa pewarisan terhadap hak cipta intelektual hanya dapat berlangsung karena adanya kematian. Dalam artian bahwa tidak pewarisan apabila pewaris belum meninggal dunia. Ketentuan itu sesuai dengan pasal 831 Kitab Undang-undang Hukum Perdata. $^{32}$ Oleh karena itu, apabila terjadi peralihan hak kepemilikan terhadap hak cipta intelektual sebelum penciptanya meninggal dunia, maka tidak dapat dikategorikan sebagai warisan walaupun yang menerima hak kepemilikan itu adalah ahli waris pencipta.

Dalam konteks tersebut, ketentuan mengenai ahli waris yang berhak atas kepemilikan hak cipta intelektual tidak dijelaskan dalam Undang-undang Nomor 19 Tahun 2002 tentang Hak Cipta, akan tetapi hal itu dapat dilihat dalam Kitab Undang-Undang Hukum Perdata pada pasal 832 dan Inpres Nomor 1 Tahun 1991 tentang Kompilasi Hukum Islam. Pada

31 Lihat, Penjelasan UU Nomor 19 Tahun 2002 tentang Hak Cipta pasal 3 ayat 2 .

${ }^{32}$ Lihat, R. Subekti dan R. Tjitrosudibio, Kitab Undang-Undang Hukum Perdata, (Cet. XVII; Jakarta: Pradnya Paramita, 1983), h.207. 
pasal 832 KUH Perdata diatur bahwa yang berhak untuk menjadi ahli waris adalah para keluarga sedarah, baik sah maupun luar kawin dan si suami atau istri yang hidup terlama. ${ }^{33}$ Sedangkan dalam Kompilasi Hukum Islam yang berhak menjadi ahli waris adalah orang yang mempunyai hubungan darah dan hubungan perkawinan.

\section{PENUTUP}

\section{A. Simpulan}

Mengacu dari uraian yang telah dikemukakan, ditarik kesimpulan bahwa dalam perspektif hukum Islam hak cipta intelektual dipandang sebagai harta yang merupakan kekayaan yang timbul dari kemampuan intelektual seseorang. Oleh karena itu, hak cipta intelektual dapat diwarisi kepada ahli waris. Demikian pula dalam sistem hukum positif Indonesia, hak cipta intelektual dipandang kekayaan intelektual yang dikategorikan dalam benda tak bergerak, sehingga kepemilikan terhadap hak cipta intelektual termasuk dalam bidang hukum perdata yang dapat diwarisi dan diwariskan.

\section{B. Saran}

Berangkat dari uraian tersebut diatas, diajukan rekomendasi sebagai berikut:

1. Konsepsi kewarisan hak cipta intelektual perlu disosialisasikan kepada masyarakat agar tidak terjadi pengabaian terhadap ketentuan-ketentuan hukum dalam peralihan hak kepemilikan hak cipta intelektual kepada ahli warisnya.

2. Diperlukan kajian-kajian yang lebih intensif terhadap masalah-masalah yang berkaitan dengan hak cipta intelektual, khususnya mengenai masalah-masalah concern dengan perlindungan hukumnya. Pada gilirannya akan ditemukan hukum yang lebih memberikan jaminan atas kepemilikan dan pemeliharaan hak cipta intelektual.

\section{${ }^{33}$ Ibid.}

34 Lihat, Pasal 174 ayat 1 Kompilasi Hukum Islam, dalam Abd. Rahman, op.cit., h.156-157. 


\section{DAFTAR PUSTAKA}

Ash-Shiddiqy, Hasbi, Filsafat Hukum Islam, Cet. III; Jakarta: PT. Bulan Bintang, 1985

Bisri, Cik Hasan, (Peny), Hukum Islam dalam tatanan Masyarakat Indonesia, Cet. I; Jakarta: Logos, 1999

al-Daraini, Fathi, al-Figh al-Islami al-Muqaran Ma'a alMazahib, Damsyiq: Mathba'ah Thurbin, t. th.

Departemen Pendidikan dan Kebudayaan, Kamus Besar Bahasa Indonesia, Cet. III; Jakarta: Balai Pustaka, 1990

Hosen, Ibrahim, Fungsi dan Karakteristik Hukum Islam dalam Kehidupan Umat Islam, dalam Amrullah Ahmad SF, Dimensi Hukum Islam dalam Sistem Hukum Nasional, Cet. I; Jakarta: Gema Insani Press, 1996

Khaldun, Ibn, Muqaddimah, Qahirah: Mathba'ah Mustafah Muammad, t. th.

Mughniyah, Muh. Jawad, al-Fiqh 'ala Mazahib al-Khamzah, diterjemahkan oleh Afif Muhammad dengan judul, Fikih Lima Mazhab, Jilid II, Cet. I; Jakarta: Basrie Press, 1994

Purwosutjipto, H.M.N., Pengertian Pokok Hukum Dagang Indonesia, Jakarta: Jambatan, 1988

Rahman, Abd., Kompilasi Hukum Islam di Indonesia, Cet. I; Jakarta: Akademika, 1992

Rofiq, Ahmad, Hukum Islam Indonesia, Cet. II; Jakarta: Raja Grafindo Persada, 1997

al-Salam, al-'Ilz bin Abd., Qawa'id al-Ahkam, II, Qahirah: Maktabah al-Kulliyat al-Ashariyah, 1968

Simatupang, Richard Burton, Aspek Hukums dalam Bisnis, Cet. I; Jakarta: Rineka Cipta, 1996

Tim Penyusun, Kamus Besar Bahasa Indonesia, Cet. II; Jakarta: Balai Pustaka, 2002

Undang-Undang Nomor 19 Tahun 2002 tentang Hak Cipta. 
Yanggo, Huzaimah T., dan Hafiz Anshary (ed.), Problematika Hukum Islam Kontemporer, Cet. I; Jakarta: LSIK, 1995

Zein, Satria Efendi M., Analisis Fiqh, dalam Mimbar Hukum Akatualisasi Hukum Islam, Nomor 30 Thn. VIII, 1997, Jakarta: Al-Hikmah dan Ditbinbapera Islam

Zuhad, Pandangan Hukum Islam Terhadap pembajakan dan Akibat Hukumnya, dalam Huzaimah T. Yanggo dan Hafiz Anshary (ed.), Problematika Hukum Islam Kontemporer, Cet. I; Jakarta: LSIK, 1995

al-Zuhaily, Wahbah, al-Figh al-Islam wa Adillahtuh, Juz VIII, Cet. III; Beirut: Dar al-Fikr, 1989. 